\title{
Climate change impacts on Ontario wind power resource
}

Yao Yao ${ }^{1}$, Gordon H Huang ${ }^{2,3^{*}}$ and Qianguo Lin $^{4}$

\begin{abstract}
Background: The availability and reliability of wind power depend largely on current and future climate conditions, which may vary in the context of climate change. A high resolution regional climate model (PRECIS) was used for dynamic downscaling of the future wind speed over Ontario. The changes of wind power density and power production were further investigated through case studies.

Results: The spatial pattern and the magnitude of wind speed from PRECIS simulation, Wind Energy Atlas and the observation indicated a successful climate simulation. Climate modelling indicated that there would be a decrease of up to $5 \%$ in wind speed over southern Ontario from present to the period of 2071-2100. It was showed in the case studies that the changes of wind power production were not in proportion to the changes of average wind speed, due to the variations of wind speed distribution.

Conclusion: The decrease of projected wind speed would be more intense in A2 than in B2 scenario, showing statistically significant differences in the grid cell mean wind speed. The changes of wind power production may not be in proportion to the changes of average wind speed. It would be reasonable to develop onshore or offshore wind energy industry around Georgian Bay and James Bay, considering the projected increasing wind speeds within these areas.
\end{abstract}

Keywords: Climate change, Regional climate model, Wind speed, Power production

\section{Background}

Around the world, the effects of climate change are already upon us. Many countries have included renewable energy systems in their future energy plans so that they can produce reliable and environmentally friendly energy. Compared to the environmental effects of traditional energy sources, the environmental effects of wind power are relatively minor (Dvorak et al., 2010; Migoya et al., 2007). Wind power consumes no fuel, and emits no air pollution. However, it's advisable to realize that wind energy is based on natural forces, which means it's highly spatial correlated, and is also variable over time. Moreover, the availability and reliability of wind power depend greatly on current and future climate conditions, which also may vary in light of possible global climate

\footnotetext{
* Correspondence: huang@iseis.org

${ }^{2}$ Institute for Energy, Environment and Sustainable Communities, University

of Regina, Regina, Saskatchewan, Canada S4S OA2

${ }^{3}$ Institute for Energy, Environment and Sustainability Research, UR-NCEPU,

North China Electric Power University, Beijing 102206, China

Full list of author information is available at the end of the article
}

change (Cai et al., 2011; Huang \& Qin, 2008; Lin et al., 2011). Ontario is at the forefront of wind energy in Canada. According to Canadian Wind Energy Association, Ontario takes up 36\% of current wind power generated in the country, and its capacity will continue to increase dramatically in the future. In terms of regional energy planning, there is an urgent need to refine global climate change impacts down to regional level in order to understand its trend and longer-term effect to avoid energy safety and economical risks.

It is widely recognized that the increasing of greenhouse gas (GHG) emission in atmosphere has effects on global climate. A range of GHG emission scenarios have been developed in the IPCC Special Report on Emissions Scenarios that reflect a number of different ways in which the world might develop and the consequences for population, economic growth, energy use and technology (Nakicenovic et al., 2000). To estimate the effect that these emissions have on the global climate, global climate models (GCMs) are employed (Smithson, 2002). GCMs describe important physical elements and processes in the

\section{实}

(c) 2012 Yao et al.; licensee Springer. This is an Open Access article distributed under the terms of the Creative Commons Attribution License (http://creativecommons.org/licenses/by/2.0), which permits unrestricted use, distribution, and reproduction in any medium, provided the original work is properly cited. 
atmosphere, oceans and land surface that make up the climate system. One disadvantage of GCMs is their scale, which is typically a few hundred kilometers in resolution. In order to link the impacts of climate change to practical problems such as local wind power availability, we need to predict changes on much finer scales. The GCM modeling results are required to be downscaled to higher resolution. Generally, there are two types of downscaling techniques. One is statistical downscaling. The other one is dynamic downscaling. The dynamic one is through the use of regional climate models (RCMs), which have the potential to improve the representation of the climate information which is important for assessing a region's vulnerability to climate change. PRECIS (Providing Regional Climates for Impacts Studies) is a regional modeling system that can be run over any area of the globe to provide regional climate information for impacts studies. Boundary conditions are required at the limits of the model's domain to provide the meteorological forcing for the RCM.

In the past decade, much attention in the climate change researches has been focused on the potential impacts on temperature and precipitation. Recently, a growing number of studies have looked at potential impacts on renewable energy resources, and on wind power (Sailor et al., 2008). In particular, it was found that wind power potential throughout Finland might increase by $2-10 \%$ under conditions of climate change Using GCM output from the Hadley (Venäläinen et al., 2004). Pryor (Pryor et al., 2005a) has found that annual wind power potential over Northern Europe under the IPCC A2 and B2 scenarios was highly dependent on the boundary conditions used in Rossby Centre coupled Regional Climate Model (RCAO). Using empirical downscaling of five GCMs for 46 stations over Northern Europe, it's shown a slight decrease in mean wind speeds under a 2080-2100 climate projection (Pryor et al., 2005b). Breslow \& Sailor explored climate change implications for wind power in California and Texas using neural network-based downscaling (Breslow \& Sailor, 2002). In the recent research using statistically downscaling tools (Sailor et al., 2008), the summertime wind speeds in the Northwest U.S. may decrease by $5-10 \%$ which suggests a $40 \%$ reduction in summertime generation potential. RCM was also used in Brazil to find out that the wind power potential in Brazil would not be jeopardized in the future due to possible new climate conditions (Breslow \& Sailor, 2002). However, within all these researches, uncertainty remains a bottleneck. The models, methods and scenarios used are so sophisticated that the massive uncertainty is immeasurable, which leads to a relatively low credibility of the findings. There is also a lack of studies on the substantial impacts of changing wind speed on the actual wind power production.
Therefore the objective of this research is to: a) determine whether the wind speed over Ontario generated by PRECIS using boundary conditions supplied from HadAM3H GCM during the control period (1961-1990) exhibit reasonable and realistic features as other reanalysis data products. b) determine if there are substantial differences between near-surface wind speed calculated for the control run versus a prognostic period (2071-2100) for either of two IPCC emission scenarios (A2 and B2). c) investigate the detailed impacts on wind power utilization as the result of the changes of the wind speed.

\section{Methodology \\ Study area and data acquisition Study area}

The territory of Ontario is often broken into two regions, Northern Ontario and Southern Ontario. The great majority of population $(94 \%$, i.e. $36.3 \%$ of the population of Canada) and arable land in Ontario is located in the south, which contrasts with its relatively small land area in comparison to the north. Ontario's existing installed generation capacity includes nuclear, coal, oil, gas, hydroelectric, wood and waste-fuelled generation, which results in a total installed capacity of approximately $35485 \mathrm{MW}$. The wind energy only constitutes about $3 \%$ of the total capacity, while this percentage is $30 \%$ in Denmark. The total installed wind power capacity is 1208 megawatts, or 2.7 percent of Ontario's total installed capacity. Ontario has 36\% of Canada's installed capacity for wind-generated electricity. The Ontario Power Authority's (OPA) Integrated Power System Plan had called for $4600 \mathrm{MW}$ of wind energy by 2020. In 2009, Ontario's new Green Energy Act came into force with a feed-in-tariff and (FIT) new transmission investments that make it likely that this target will be exceeded. Approximately $8000 \mathrm{MW}$ of wind energy projects have submitted applications for FIT contracts. Currently, $2500 \mathrm{MW}$ of capacity will be able to connect to the grid, but transmission upgrades are planned to allow the connection of significantly more capacity over the next few years (Pereira de Lucena et al., 2010). With such a fast growing rate of wind power, there is a growing need for a long-term outlook of the wind speed variation.

\section{Climate change projections}

PRECIS is a high resolution climate model that covers a limited area of the globe, typically $5000 \times 5000 \mathrm{~km}$, with a typical horizontal resolution of $50 \mathrm{~km}$. The Hadley Centre's current version of the PRECIS (HadRM3P) is based on HadAM3H, an improved version of the atmospheric component of the latest Hadley Centre coupled AOGCM. HadRM3P has been used with horizontal resolutions of 50 and $25 \mathrm{~km}$ with 19 levels in the atmosphere (from the surface to $30 \mathrm{~km}$ in the stratosphere) 
length was set as 30 years (1961-1990 for baseline and 2071-2100 for projection). It is important to run RCMs to generate more than one of the future climate scenarios implied by different emissions scenarios in order to start to quantify the "emissions" uncertainty in the predictions. For PRECIS, boundary data was available from two 31 year integrations of the HadAM3P atmosphereonly atmosphere global model. One of them provides a simulation of the climate of 2070-2100 under A2 emission scenario and the other is associated with B2 emission scenario.

\section{Reanalyzed climate data}

To provide independent assessment of the PRECIS output during the control period, the reanalyzed Canadian Wind Energy Atlas was used. This data set was produced by statistical-dynamical downscaling method. The method consists of using large scale long term atmospheric data and their statistical properties to run a mesoscale model and post-process its output in order to get a small scale picture of atmospheric motion. The NCAR/NCEP reanalysis (Frey-Buness et al., 1995) was chosen as its data base. The simulations are performed with the Mesoscale Compressible Community (MC2) model (Kalnay et al., 1996) to provide $5 \mathrm{~km}$ resolution output. This data set

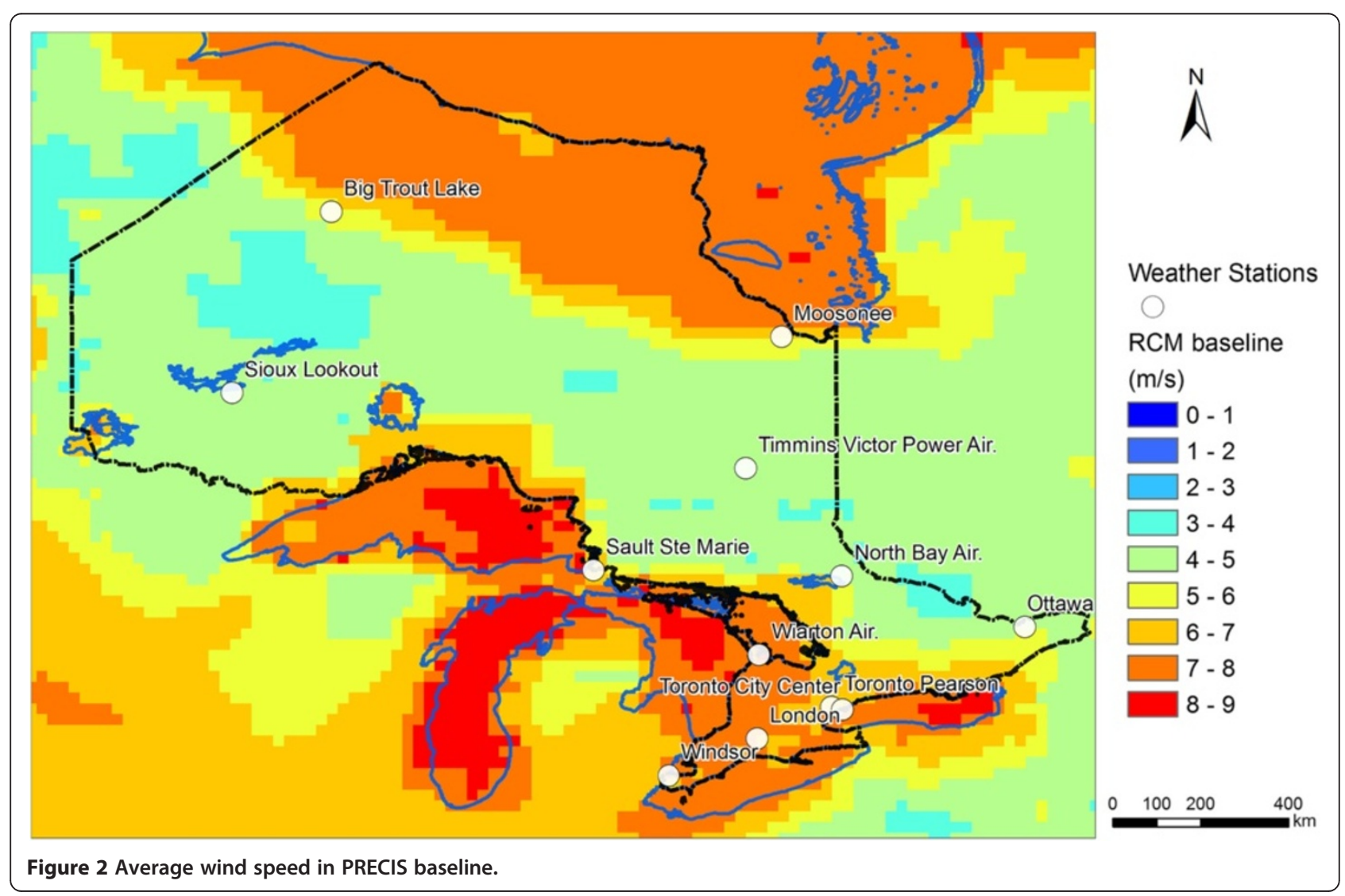


was considered as the representative of statistical wind properties for the period of 1958 to 2000.

\section{Observed climate data}

To analyze the historical weather condition and to evaluate the performance of PRECIS control run, observed weather data was collected from Environmental Canada. Twelve weather stations at major cities in Ontario were selected. The data was downloaded from National Climate Data and Information Archive on Environment Canada website (Benoit et al., 1997). This archive, operated and maintained by Environment Canada, contains official climate and weather observations for Canada. Climate elements, such as temperature, precipitation, relative humidity, atmospheric pressure, wind speed, wind direction, visibility, cloud types, cloud heights and amounts, soil temperature, evaporation, solar radiation and sunshine as well as occurrences of thunderstorms, hail, fog or other weather phenomena are warehoused in a digital database.

\section{Methods}

The workflow of this research is presented in Figure 1. In order to evaluate the performance of PRECIS over Ontario region, the output of its baseline run (19611990) was compared with the Canadian Wind Energy Atlas in terms of average wind speed and its spatial pattern. Also, the observed data was used as point samples to validate both sets of wind speed, by comparisons between the observed wind speed, and wind speed of the covering grid of Canadian Wind Energy Atlas and PRECIS. Then the differences between projections under two scenarios and the baseline were calculated respectively to evaluate the wind speed change in each scenario.

To explore the impact of potential changes in the wind speed, the energy density in each grid cell was computed based on wind speed value. Assuming $80 \mathrm{~m}$ hub-height, the $10 \mathrm{~m}$ wind speed value from climate model was transformed to the $80 \mathrm{~m}$ speed:

$$
\frac{u_{1}}{u_{2}}=\left(\frac{z_{1}}{z_{2}}\right)^{1 / 7}
$$

where $u(\mathrm{~m} / \mathrm{s})$ is the wind speed at the level of $z(\mathrm{~m})$. The power density can be calculated using:

$$
\frac{P}{A}=\frac{1}{2} \rho u^{3}
$$

where $P / A\left(\mathrm{~W} / \mathrm{m}^{2}\right)$ is the power density, $\rho$ is the air density $\left(\mathrm{kg} / \mathrm{m}^{3}\right)$ and $u$ is the wind speed $(\mathrm{m} / \mathrm{s})$.

The most obvious impact of climate change on the wind power resource would be the changes on power production. The Weibull probability density function

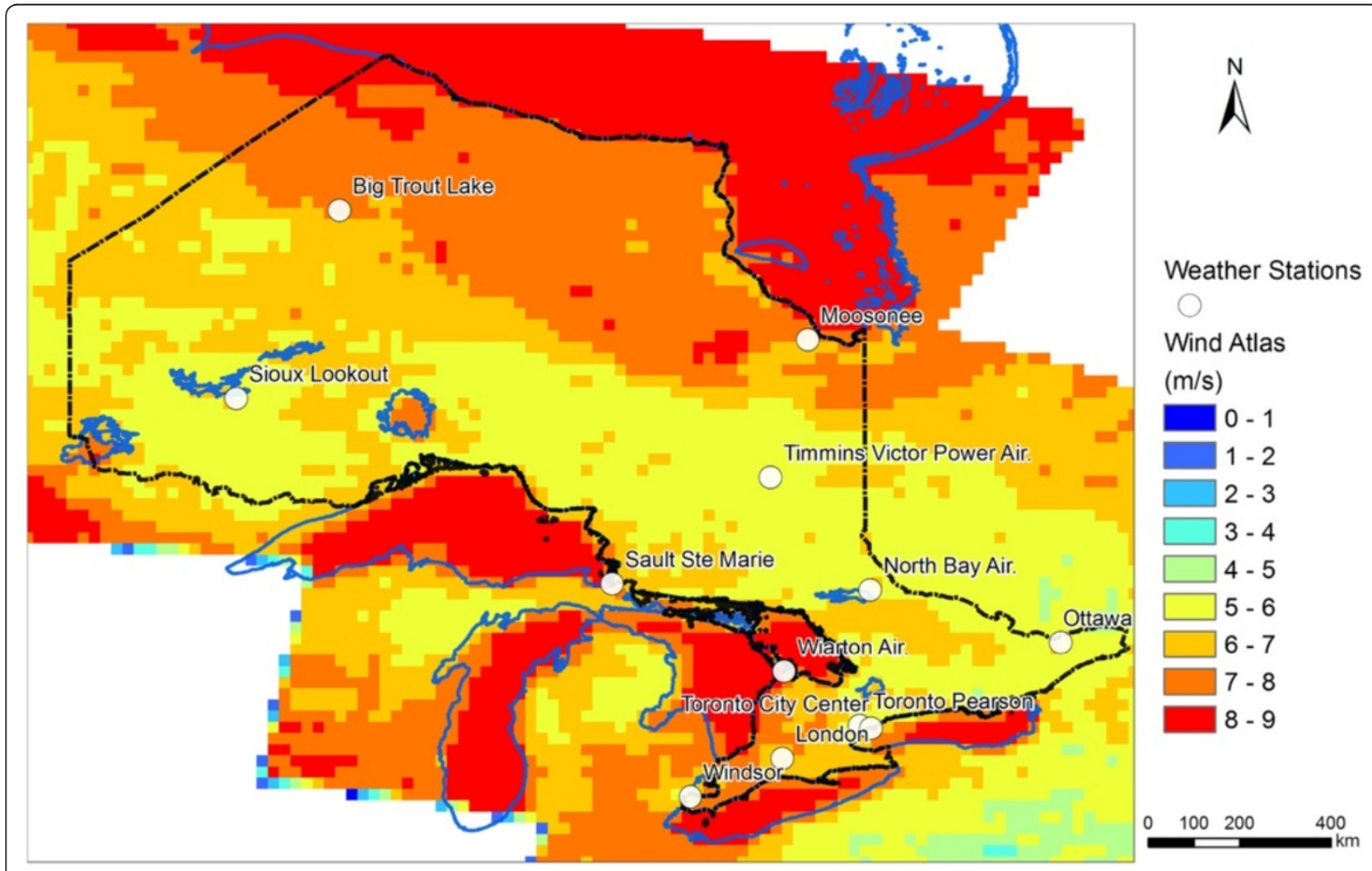

Figure 3 Average wind speed in Canadian Wind Energy Atlas. 
was adopted and be fitted to hub-high wind speed distribution. This distribution is often used in wind energy engineering, as it conforms well to the observed longterm distribution of mean wind speeds for a range of sites (Manwell et al., 2009). The Weibull probability density function expresses the probability $f(\mathrm{x})$ to have a wind speed $x$, as follow (Hiester \& Pennell, 1981):

$$
f(x)=\left(\frac{k}{C}\right)\left(\frac{x}{C}\right)^{k-1} \exp \left[-\left(\frac{x}{C}\right)^{k}\right]
$$

where $k$ is the shape factor, specified by the user. The shape factor will typically range from 1 to 3 . For a given average wind speed, a lower shape factor indicates a relatively wide distribution of wind speeds around the average while a higher shape factor indicates a relatively narrow distribution of wind speeds around the average. A lower shape factor will normally lead to a higher energy production for a given average wind speed.

The actual output of a wind turbine is related directly to its: a) start-up speed: the speed at which the rotor and blade assembly begins to rotate, b) cut-in speed: the minimum wind speed at which the wind turbine will generate usable power, c) rated speed: the minimum wind speed at which the wind turbine will generate its designated rated power, d) cut-out speed: the safety speed which protects the wind turbine from damage.

The power production $P w$ of a wind turbine can be calculated by:

$$
P w=\int_{x i}^{x o} p(x) f(x) d x
$$

where $x i$ and $x o$ is the cut-in and cut-off speed of the turbine; $p(x)$ is the power curve of a specific turbine.

\section{Results and discussion}

\section{Validation of climate model}

Figures 2 and 3 indicated that the PRECIS baseline (1961-1990) output showed good agreement with the Canadian Wind Energy Atlas in terms of the spatial patterns. However, the overall magnitude of wind speed in Canadian Wind Energy Atlas was higher than in PRECIS. The comparison of two sets of data was done by subtraction; the result is showed in Figure 4. The PRECIS simulation tend to make a higher evaluation of wind speed along the shorelines of the Great Lakes and Hudson Bay, while it was lower than the Canadian Wind Energy Atlas within the Canadian Shield region, especially at the north part. The Mean Absolute Difference

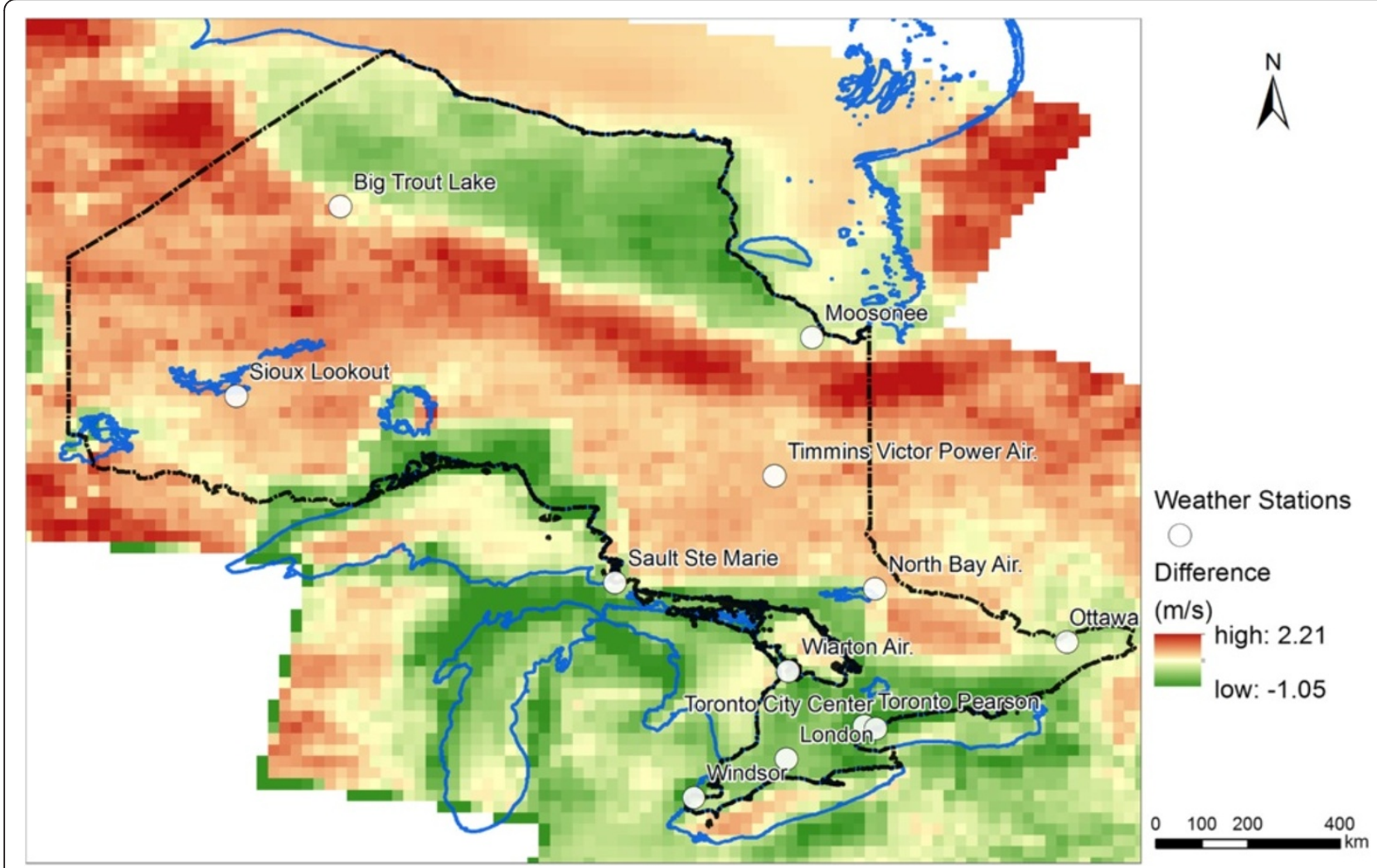

Figure 4 Wind speed difference between Canadian Wind Energy Atlas and PRECIS baseline. 


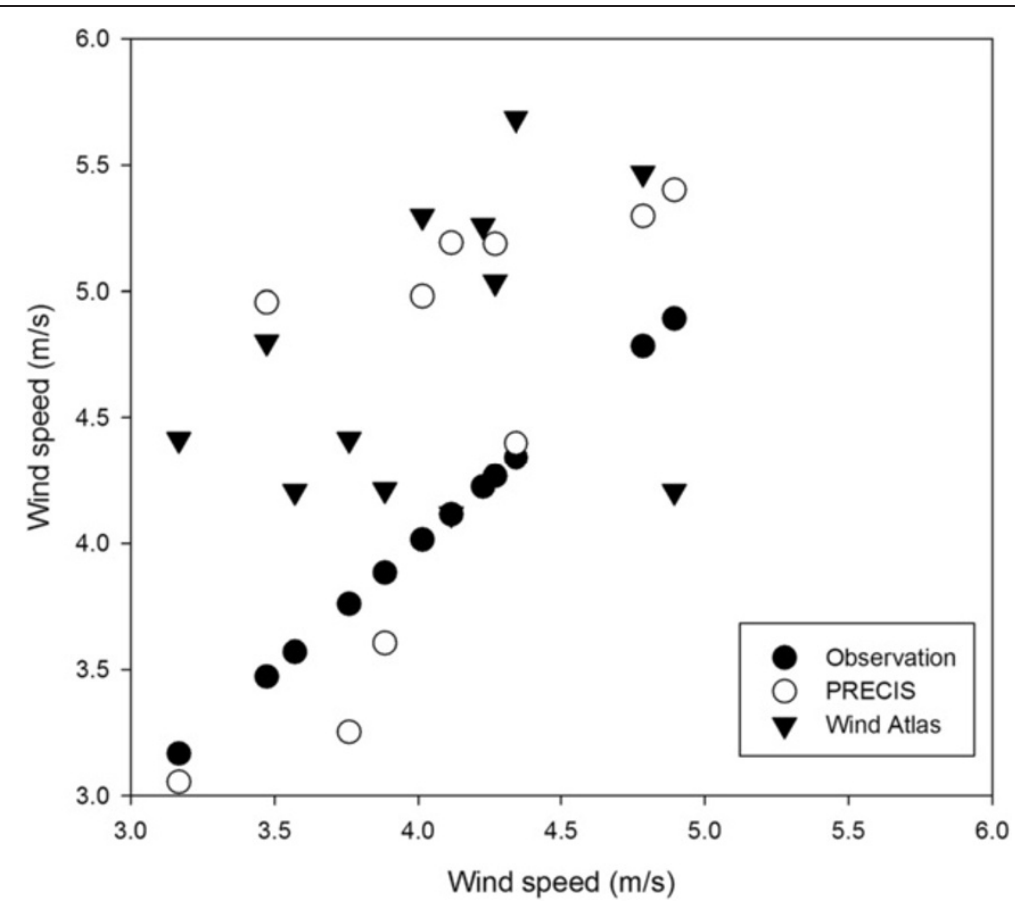

Figure 5 Comparison of wind speed from observation, Canadian Wind Energy Atlas and PRECIS baseline at major cities.

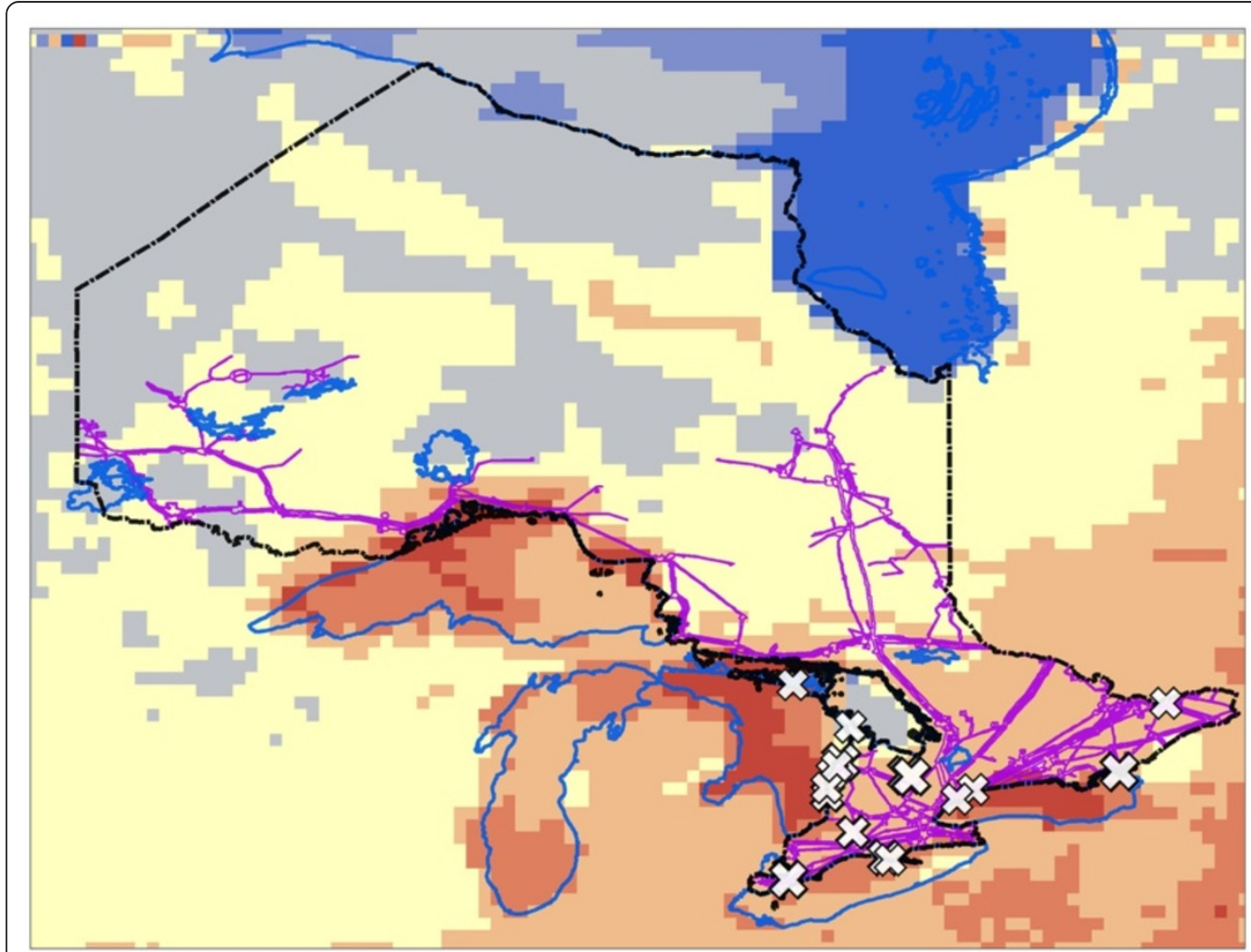

Wind Farm (MW)

\& $0-10$

\& $10-50$

\50-100

W $100-200$

Transmission Line

A2 Variation (\%)

$<-5 \%$

$-5 \%$ to $-3 \%$

$-3 \%$ to $-1 \%$

$-1 \%$ to $1 \%$

$1 \%$ to $3 \%$

$3 \%$ to $5 \%$

$>5 \%$

$0 \quad 100200$

Figure 6 Wind speed variation under A2 scenario. 
(MAD) between PRECIS output and observation was $0.73 \mathrm{~m} / \mathrm{s}$, and was $0.84 \mathrm{~m} / \mathrm{s}$ between Canadian Wind Energy Atlas and observation. The three set of wind speed data was compared at 12 weather stations in the major cities in Ontario (Windsor Airport, London Int'l Airport, Toronto Pearson Int'l Airport, Toronto City Center (Island) Airport, Ottawa Int'l Airport, Wiarton Airport, North Bay Airport, Sault Ste Marie Airport, Sioux Lookout, Timmins Victor Power Airport, Big Trout Lake, Moosonee Airport). The result was presented in Figure 5. The three series are: observation versus observation, RCM baseline versus observation, and Canadian Wind Energy Atlas versus observation. The pattern showed in this figure was in accordance with Figure 4, that PRECIS simulate higher wind speed around The Great Lakes. However, since both PRECIS and Wind Energy Atlas generate grid-cell averaged wind speed, the bias was inevitable when comparing with spot measurement. It is also indicated that there was no significant bias between the PRECIS baseline run and Canadian Wind Energy Atlas. As the Canadian Wind Energy Atlas was acknowledged to be a plausible representation of the wind speed distribution, the PRECIS baseline run was therefore considered to be a validated and successful.

\section{Changes of wind speed}

Once the baseline simulation was validated, it's reasonable to assume that the used climate model was able to reflect the meteorological processes which it was designed to capture. Therefore, by comparing the projected climate under various scenarios and the baseline, the possible changes of the future climate can be investigated.

The grid differences of wind speed between A2, B2 projection and baseline ranged from $-0.65 \mathrm{~m} / \mathrm{s}$ to $0.82 \mathrm{~m} / \mathrm{s}$ and $-0.55 \mathrm{~m} / \mathrm{s}$ to $0.37 \mathrm{~m} / \mathrm{s}$, respectively. The Mean Absolute Difference (MAD) and its standard deviation were $0.016 \mathrm{~m} / \mathrm{s}$ and $0.212 \mathrm{~m} / \mathrm{s}$ under A2 scenario, and $0.002 \mathrm{~m} / \mathrm{s}$ and $0.122 \mathrm{~m} / \mathrm{s}$ under B2 scenario. Although the MAD was small, the changes of wind speed required detailed interpretation by referring to the spatial distribution, which was not homogeneous considering the relatively high standard deviation.

The wind speed variations under A2 and B2 scenarios were presented in Figure 6 and Figure 7. The percentage of variation was derived by subtracting the wind speed in baseline from projected for each grid, and divided by the baseline wind speed. Generally, there would be a trend that wind speed in Great Lakes region would decrease, while there would be greater wind speed around and over northern water bodies. This trend would be
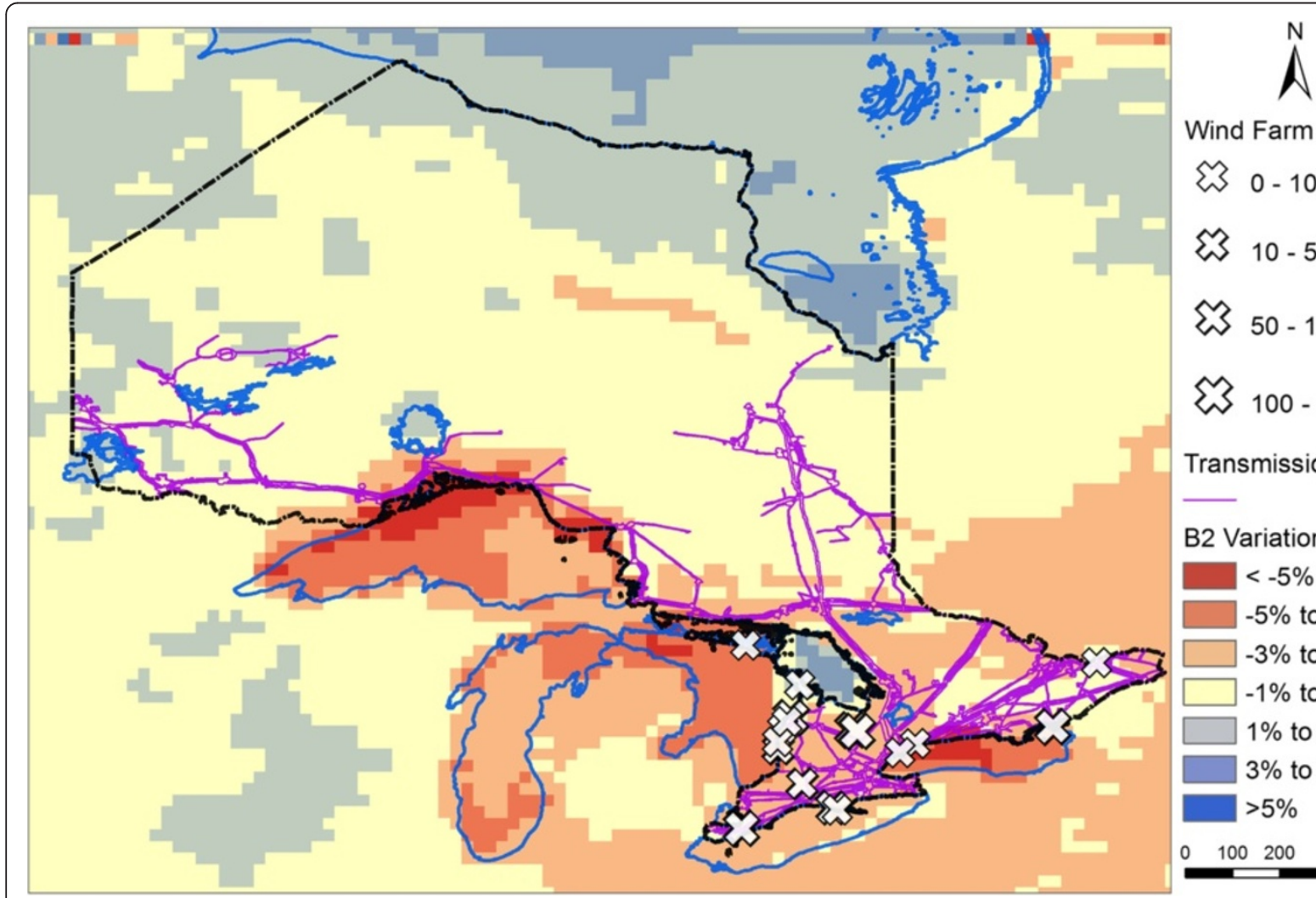

Wind Farm (MW)

ह $0-10$

\& $10-50$

$\sqrt{50-100}$

$100-200$

Transmission Line

B2 Variation (\%)

$<-5 \%$

$-5 \%$ to $-3 \%$

$-3 \%$ to $-1 \%$

$-1 \%$ to $1 \%$

$1 \%$ to $3 \%$

$3 \%$ to $5 \%$

$>5 \%$

$0 \quad 100 \quad 200 \quad 400$

Figure 7 Wind speed variation under B2 scenario. 
more intense in A2 scenario than in B2 (Figure 8). Therefore the low MAD value was the result of the averaging of positive and negative variations. In most areas of southern Ontario, there would be a deduction of average wind speed ranging from $1 \%$ to $3 \%$ by the period of 2071-2100, or even higher to $5 \%$ at some grids in both scenarios. As most of the Ontario's population settles in the southern region, they would probably experience a lower near surface wind in the long-term future. The trend of decreasing wind speed in north America was also reported by Breslow and Sailor (Breslow \& Sailor, 2002), who used GCMs to investigate the potential impacts of climate change on wind speeds, predicting that the US continental will see reduced wind speeds of 1.0 to $3.2 \%$ in the next 50 years, and 1.4 to $4.5 \%$ over the next 100 years.

\section{Impacts on wind power resource}

Figure 6 and Figure 7 also shows the major wind farms in Ontario, it could be inferred that most of the turbines would still be in the suitable zone where the average wind speed exceeds $6 \mathrm{~m} / \mathrm{s}$. However, as can be seen from the figures, most of Ontario's major wind farms were built in the Great Lakes region, where the wind speed would likely to be lower, in which case the wind farms might be facing a decreasing power production. As can be calculated by Eq. (2), the wind energy density would drop down dramatically as wind speed decreases, because its value is proportional to the third power of the wind speed. Take Erie Shores Wind Farm as an example, it is located at northern shoreline of Lake Eire, installed in 2006 with 66 GE 1.5 MW Turbines and total installed Capacity of $99 \mathrm{MW}$. According to the projected results, the average wind speed in 2071-2100 would decrease by 4.9\% and 3.2\% under A2 and B2 scenarios respectively. That equaled to a significant wind power density deduction of $14.0 \%$ and $9.3 \%$ under A2 and B2 scenarios.

To investigate the detailed impact on the actual power production of wind turbines, the Weibull distribution (Eq. (3)) was fitted to the $80 \mathrm{~m}$ high equivalent wind speed for the years of 1990 and 2070 (under A2 scenario) at Erie Shores Wind Farm (Figure 9). The figure indicated that the projected future wind speed distribution would be more scattered, and the peak speed would be lower. The energy production of a GE Energy 1.5SLE wind turbine was then calculated based on Eq. (4). The results showed that the difference of power production between the two Weibull curves was 9.23\%, which was lower than the estimated power density deduction. The reason for that was because the power production of a wind turbine ceased to rise while the wind speed exceeded a certain value, which is $10 \mathrm{~m} / \mathrm{s}$ for the GE

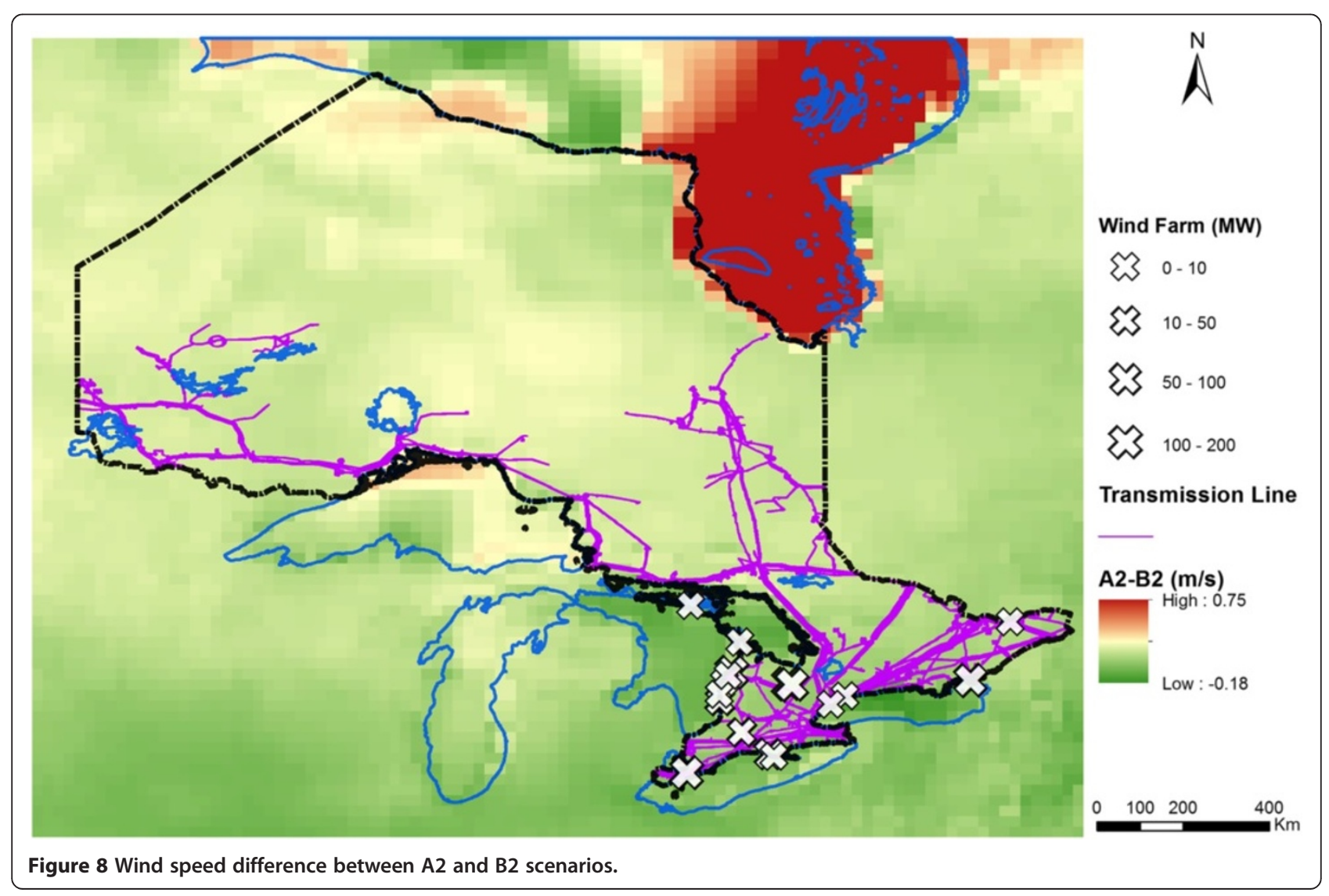



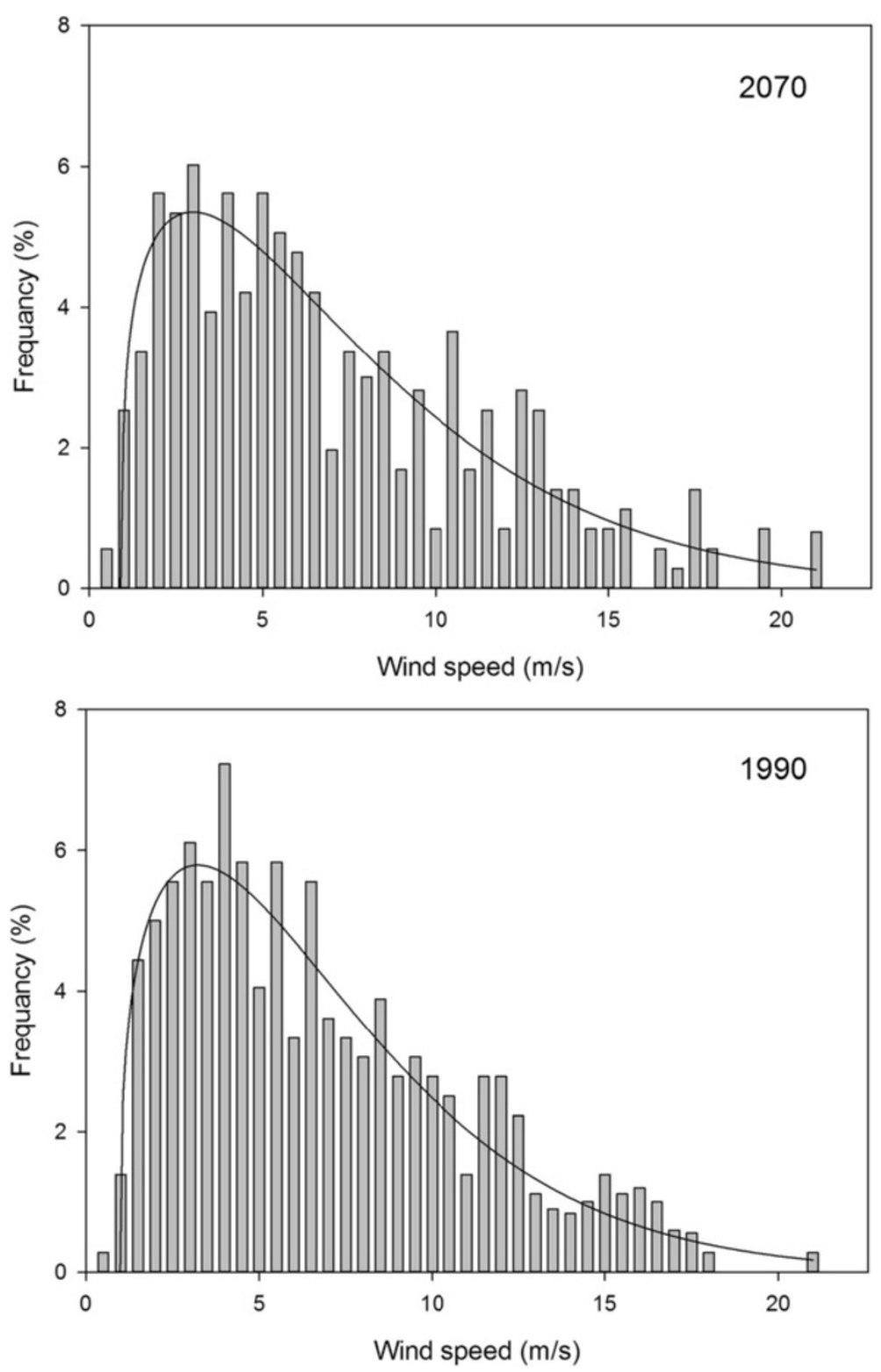

Figure 9 Projected wind speed distribution at Erie Shores Wind Farm in the year of 2070 (upper) and 1990 (lower).

Energy 1.5SLE model. In another word, the wind power density estimation was not a perfect index for wind power production, since it merely rely on the average wind speed and was not able to account for the features of the wind turbines. However, the tradeoff of considering the wind turbine specifications is the less representativeness and comparability.

Despite the pessimistic results of the projection, it should be noticed that the time span of this variation was about 100 years, while the lifespan of a normal wind turbine is 20 to 25 years. Thus, it's possible to consider adaptation strategies in order to mitigate the impact of climate change, considering the long-term wind speed variation. From Figures 7 and 8, it's obvious that the future wind speed at Georgian Bay (to the west of Lake Huron) and James Bay would be higher. Using the same method for the Erie Shores case study, the changes of onshore and offshore wind power density and wind power production at Georgian Bay and James Bay were calculated. As showed in Table 1, the growth of offshore wind power potential would be higher than onshore. There would be a dramatic increase of $33.1 \%$ in offshore wind power density at James Bay, while the changes of wind power production was much lower (15.7\%) due to the same reason above. It should be noted that the change of power production was based on particular model of 
Table 1 Variations (\%) of wind speed, power density and power production at studied locations under A2 (B2) scenario in $\mathbf{2 0 7 0}$

\begin{tabular}{lccc}
\hline \multicolumn{1}{c}{ Location } & \multicolumn{2}{c}{ Wind Speed Power Density Power Production } \\
\hline Erie Shores & $-4.9(-3.2)$ & $-14.0(-9.3)$ & $-9.2(-7.2)$ \\
James Bay, onshore & $2.1(1.2)$ & $6.4(3.6)$ & $5.4(3.1)$ \\
James Bay, offshore & $10.0(4.2)$ & $33.1(13.1)$ & $15.7(8.6)$ \\
Georgian Bay, onshore & $1.4(2.0)$ & $4.3(6.1)$ & $3.9(4.8)$ \\
Georgian Bay, offshore & $2.9(4.6)$ & $9.0(14.4)$ & $6.3(9.2)$ \\
\hline
\end{tabular}

wind turbine. The difference between power density and power production would be lower if a turbine that can make full use of the wind power was chosen.

Currently, many wind farms around Georgian Bay has already been built and the nearby transmission lines also provide support for the development of wind energy. It's reasonable to consider Georgian Bay's shoreline as a potential hotspot for wind energy in the climate change context. As for James Bay, the wind energy potential there is abundant and would keep increasing in the future projections. There is also transmission line connecting hydropower stations at Abitibi River and Mattagami River. But the extreme weather in this region, the cold weather specially, must be solved technically before initiate any wind farm project. In a cold climate, icing represents one of the biggest challenges to the operation of wind turbines. Wind turbines must be able to sustain at least limited icing without incurring damage that would prevent normal operation.

The above finding also suggests offshore wind farm as an alternative regarding the increasing wind energy potential above the water surfaces over Georgian Bay and James Bay. While offshore wind energy is undergoing rather rapid global growth, Canada does not yet have any offshore wind facilities installed. However, the potential resources for this technology in Canada are amply at present and in the projected future. Although offshore wind turbines can be more costly to install and operate, they offer several distinct advantages over their onshore counterparts: (1) in general, they can be installed closer to coastal urban load centers, where most electrical energy demand exists, (2) offshore winds are faster and more consistent at lower vertical heights due to the reduced surface roughness over the ocean (Manwell et al., 2009), and (3) offshore turbines and components are not limited by roadway shipping constraints, so higher capacity turbines can be installed.

\section{Conclusion}

The results corresponding to the objectives are as follows: a) The spatial pattern of wind speed was similar between PRECIS simulation (1961-1990) and Canadian Wind Energy Atlas. The mean absolute difference of the mean wind speed between PRECIS simulation, Wind Energy Atlas and the observed data were 0.73 and $0.84 \mathrm{~m} / \mathrm{s}$ respectively, indicating a successful climate simulation. b) The PRECIS simulation (2071-2100) suggested decreasing wind speed over the populated southern Ontario relative to the baseline period. These changes would be more intense in the A2 than in B2 scenario, and lead to statistically significant differences in the grid cell mean wind speed. c) Based on case studies around Erie Shores, James Bay and Georgian Bay, it was showed that the changes of wind power production may not be in proportion to the changes of average wind speed, due to the possible variations of wind speed distribution. It would be reasonable to develop onshore or offshore wind energy industry around Georgian Bay and James Bay, considering the projected increasing wind speeds within these areas.

Although it would provide more valuable information, the analysis of temporal variations of wind speed was not conducted due to limited computational capacity. It should also be noted that the results of this work depend fundamentally on the quality of the climate projections on which it is based. Improvements could be made through a more thorough analysis, including wind speed seasonality, and projections from different GCM configurations and downscaling methods. These could aid in coping with some of the uncertainties and add useful information about the vulnerability of wind power.

Competing interests

The authors declare that they have no competing interests.

\section{Acknowledgements}

This research was supported by the Program for Innovative Research Team (IRT1127), the MOE Key Project Program (311013), the Natural Science and Engineering Research Council of Canada, and the Major Project Program of the Natural Sciences Foundation (51190095).

\section{Author details}

${ }^{1}$ Faculty of Engineering and Applied Science, University of Regina, Regina, Saskatchewan S4S 0A2, Canada. ${ }^{2}$ Institute for Energy, Environment and Sustainable Communities, University of Regina, Regina, Saskatchewan, Canada S4S 0A2. ${ }^{3}$ Institute for Energy, Environment and Sustainability Research, UR-NCEPU, North China Electric Power University, Beijing 102206, China. ${ }^{4}$ Institute for Energy, Environment and Sustainability Research, URNCEPU, North China Electric Power University, Beijing 102206, China.

\section{Authors' contribution}

YY carried out the data collection, results analysis and drafted the manuscript. GH and QL carried out the works related to climate modelling. All contributed jointly and equally to the discussion of the manuscript. All authors read and approved the final manuscript.

Received: 18 April 2012 Accepted: 14 August 2012

Published: 14 August 2012

\section{References}

Benoit R, Desgagné M, Pellerin P, Pellerin S, Chartier Y, Desjardins S (1997) The Canadian MC2: a Semi-Lagrangian, semi-implicit wideband atmospheric model suited for finescale process studies and simulation. Mon Weather Rev 125(10):2382-2415 
Breslow PB, Sailor DJ (2002) Vulnerability of wind power resources to climate change in the continental United States. Renew Energy 27(4):585-598

Cai YP, Huang GH, Tan Q, Liu L (2011) An integrated approach for climatechange impact analysis and adaptation planning under multi-level uncertainties. Part II. Case study. Renew Sustain Energy Rev 15(6):3051-3073

Dvorak MJ, Archer CL, Jacobson MZ (2010) California offshore wind energy potential. Renew Energy 35(6):1244-1254

Frey-Buness F, Heimann D, Sausen R (1995) A statistical-dynamical downscaling procedure for global climate simulations. Theor Appl Climatol 50(3):117-131

Hiester TR, Pennell WT (1981) The siting handbook for large wind energy systems. WindBooks, Rockville Centre, N.Y

Huang GH, Qin XS (2008) Editorial: Climate Change and Sustainable Energy Development. Energy Sources, Part A: Recovery, Utilization, and Environmental Effects 30(14):1281-1285

Kalnay E, Kanamitsu M, Kistler R, Collins W, Deaven D, Gandin L, Iredell M, Saha S, White G, Woollen J, Zhu Y, Leetmaa A, Reynolds R, Chelliah M, Ebisuzaki W, Higgins W, Janowiak J, Mo KC, Ropelewski C, Wang J, Jenne R, Joseph D (1996) The NCEP/NCAR 40-Year Reanalysis Project. Bull Am Meteorol Soc 77 (3):437-471

Lin QG, Huang GH, Bass B (2011) Impacts from climate change and adaptation responses on energy economy and greenhouse gas emissions in the Toronto-Niagara Region, Canada. Energy Sources, Part A: Recovery, Utilization, and Environmental Effects 33(17):1581-1597

Manwell JF, McGowan JG, Rogers AL (2009) Wind Turbine Design and Testing. In: Wind Energy Explained. John Wiley \& Sons, Ltd, Hoboken, New Jersey, United States, pp 311-357

Migoya E, Crespo A, Jiménez Á, García J, Manuel F (2007) Wind energy resource assessment in Madrid region. Renew Energy 32(9):1467-1483

Nakicenovic N, Alcamo J, Davis G, de Vries B, Fenhann J, Gaffin S, Gregory K, Grubler A, Jung TY, Kram T, La Rovere EL, Michaelis L, Mori S, Morita T, Pepper W, Pitcher HM, Price L, Riahi K, Roehrl A, Rogner H-H, Sankovski A, Schlesinger M, Shukla P, Smith SJ, Swart R, van Rooijen S, Victor N, Dadi Z (2000) Special Report on Emissions Scenarios: a special report of Working Group III of the Intergovernmental Panel on Climate Change

Pereira de Lucena AF, Szklo AS, Schaeffer R, Dutra RM (2010) The vulnerability of wind power to climate change in Brazil. Renew Energy 35(5):904-912

Pryor S, Barthelmie R, Kjellström E (2005a) Potential climate change impact on wind energy resources in northern Europe: analyses using a regional climate model. Clim Dyn 25(7):815-835

Pryor SC, Schoof JT, Barthelmie RJ (2005b) Climate change impacts on wind speeds and wind energy density in northern Europe: empirical downscaling of multiple AOGCMs. Clim Res 29(3):183-198

Sailor DJ, Smith M, Hart M (2008) Climate change implications for wind power resources in the Northwest United States. Renew Energy 33(11):2393-2406

Smithson PA (2002) IPCC, 2001: climate change 2001: the scientific basis. Contribution of Working Group 1 to the Third Assessment Report of the Intergovernmental Panel on Climate Change, edited by J. T. Houghton, Y. Ding, D. J. Griggs, M. Noguer, P. J. van der Linden, X. Dai, K. Maskell and C. A. Johnson (eds). Cambridge University Press, Cambridge, UK, and New York, USA, 2001. No. of pages: 881. Price $£ 34.95$, US\$ 49.95, ISBN 0-521-01495-6 (paperback). £90.00, US\$130.00, ISBN 0-521-80767-0 (hardback). Int J Climatol 22(9):1144

Venäläinen A, Tammelin B, Tuomenvirta H, Jylhä K, Koskela J, Turunen M, Vehviläinen B, Forsius J, Järvinen P (2004) The influence of climate change on energy production \& heating energy demand in Finland. Energy \& Environment 15(1):93-109

doi:10.1186/2193-2697-1-2

Cite this article as: Yao et al: Climate change impacts on Ontario wind power resource. Environmental Systems Research 2012 1:2.

\section{Submit your manuscript to a SpringerOpen ${ }^{\circ}$ journal and benefit from:}

- Convenient online submission

- Rigorous peer review

- Immediate publication on acceptance

- Open access: articles freely available online

- High visibility within the field

- Retaining the copyright to your article

Submit your next manuscript at $>$ springeropen.com 